\title{
Julian Barnes and Bauman's Tourist: Superficiality and Postmodernism.
}

\author{
John Style \\ Universitat Rovira $i$ Virgili
}

In this paper I would like to consider the work of Julian Barnes, often held up as an example of a Postmodern novelist in relationship to the work of the social scientist, Zygmunt Bauman. In particular, given the space/time constraints, I would like to juxtapose Barnes' latest novel, England, England, with some of the ideas Bauman sets out in Tourists and Vagabonds: the Heroes and Victims of Postmodernity. This was originally delivered as a lecture at the University of Virginia in 1995, and subsequently forms chapter 6 of Bauman's Postmodernity and Its discontents (1996). I will begin by summarising some of the most important points Bauman makes.

He starts by celebrating the work of Richard Rorty, whose contribution to philosophy has been to permanently undermine the discipline's traditional role of "pronouncing verdicts that exuded an air of finality" (83), what Bauman describes as a "Thanatos-driven philosophy," and to replace this by what Bauman terms an "Eros-driven, libidinal philosophy," explained as a philosophy "that fulfils itself in its perpetual unfulfilment and in asking such questions as fear final answers more than they dread the prospect of remaining unanswered" (84). Rorty goes on to suggest that a more faithful portrayal of society can be derived by taking, as "material witness," the novels of Dickens rather than the philosophy of Heidegger. Why the preference? Bauman explains Rorty's argument thus:

The 'isness' of the society Dickens narrates is to be constantly indignant and deprecating about what it has been thus far and what it is likely to become-to be forever at war with itself and take no 'yes' for an answer - to be, as Bloch would have said, constantly noch nicht geworden. The 'isness' of the world Dickens narrates is the impossibility of 'isness.' And this is, Rorty says, more true about modernity than any, however refined and sophisticated, formula which the great synthesizers may put together. (84)

Bauman suggests that this re-evaluation of the relative truth-values of literature and philosophy is part of a historical process in which philosophers such as Rorty participate. It may not reflect so much a change in philosophy as a change in the way we think about "life experience." As Bauman says, it is now trivially evident that 'common experience' is not a "void waiting to be filled with meaning, not [a] plasma to be given shape by professionals armed with hermeneutical know-how." "That experience," Bauman continues, "is rather from the start meaningful, interpreted, understood by those steeped in it" (85).

It is interesting to briefly jump to Barnes' novels, as he is a novelist often accused of being too overtly philosophical, being criticised for portraying characters who are mere ciphers for philosophical ideas, although he has also been criticised for being too philoso- 
phically lightweight, for merely playing with philosophical ideas. An example which could serve to bolster either of these contradictory opinions is the introduction, in Barnes' latest novel, of the character of the French intellectual, drafted into the planning stage of Sir Jack Pitman's "England" theme park on the Isle of Wight, whose Postmodern analysis of the project described over two or three pages, is a hilarious pastiche with plenty of appropriate name-dropping. While Barnes purposely avoids any weighty philosophical treatment of his theme, as being inappropriate in a comic novel such as the one in question, there are moments in the novel where recurrent topics of Postmodernism are embodied in the narrative, as the "life experience" of the characters. Bloch's idea of the noch nicht geworden, of "isness" as unending process of becoming, rather than one of definitively being (having become) clearly underlies the conversation between the protagonist, Martha Cochrane, and the company's resident intellectual and historian, Dr. Max. As they eat their sandwiches in the office canteen, overlooking a wetland bird sanctuary, Dr Max points out that the "authentic nature" they have in front of them is the result of planning and landscaping, and forms part of an on-going improvement scheme which, like other historical concepts, cannot be said to have ever existed in a "pure" state of being, to have had a moment of beginning, a moment in which it genuinely "was" itself. The conversation then extends to include the characters themselves, and their attitudes and behaviours, as being continually under construction (130-4).

To return to Bauman's lecture, he then goes on to discuss what he terms the detemporalisation of social space. He suggests that the seminal feature of the modern mind has been the "projection of spatial, contemporaneous difference upon the continuum of time." This powerful mix of space and time metaphors provided modern men and women with a "solid, tough [and] durable" time-space with structure, in which to live their lives. Within this mind-set, with, for example, its idea of the future as being "forward," lives could be lived as the accumulation of accomplishments which build upon each other, or as a road to follow towards a known destination. This is the world of life-long pilgrimage, of vocation, of the "life-project." This clear sense of life as a journey towards a known goal underlies the fiction of the period. One only has to think of the plot of such narratives as Jane Eyre, and David Copperfield, to see this clearly manifested-even, when struggle and setback move the protagonist apparently further from the goal rather than nearer, there is never any real doubt that such a goal exists, and will be recognized as such on its being achieved at the happy ending.

Bauman is quick to add that he is not suggesting that this time-space metaphoric structure is one about which modern men and women consciously thought, but rather that its existence can be posited by a sort of retro-projection from the present, on the strength of the fact that we have a strong sense of the loss of that structure. To quote him, "What we think the past had-is what we know we do not have" (87); and the strong sense of goal, which leads to life struggle followed by success or failure, has since evaporated into that unbearable lightness of being, in which struggles simply dissolve, and we are left not knowing whether to laugh or cry. With this dissolution comes the loss of a sense of life as pilgrimage, for "how can one live one's life as pilgrimage if the shrines and sanctuaries are moved 
around, profaned, made sacrosanct and then unholy again in a stretch of time much shorter than the journey to reach them would take?" (88).

Another sense which we know we have lost is "the facility to set apart the structure of the world from the action of humans, as the rock-steady solidity of the world out there from the pliability of human will"( 88). This is of course the underlying message of Dr Max's observation on the inauthenticity of the apparently 'natural' bird-filled landscape that Pitco workers can enjoy from the company's canteen window. It is Sir Jack's ability to grasp this truth that empowers him, and is at the base of his understanding that simulacra can come to have as much value as their originals, a philosophy upon which the success of the themepark rests. As he explains to Mark, his Project Manager:

I stood on a hill the other day and looked down an undulating field past a copse towards a river and as I did so a pheasant stirred beneath my feet. You, as a person passing through, would no doubt have assumed that Dame Nature was going about her eternal business. I knew better ... The hill was an Iron Age burial mound, the undulating field a vestige of Saxon agriculture, the copse was a copse only because a thousand other tress had been cut down, the river was a canal and the pheasant had been hand-reared by a gamekeeper. We change it all . . the trees, the crops, the animals. And now, follow me further. That lake you discern on the horizon is a reservoir, but when it has been established a few years, when fish swim in it and migrating bids make it a port of call, when the treeline has adjusted itself and little boats ply their picturesque way up and down it, when these things happen it becomes, triumphantly, a lake, don't you see? It becomes the thing itself. (60-1)

Sir Jack characterises Mark, his project Manager, as someone who "passes through" the landscape, while he, Sir Jack, realises the point is "to be in it" (60). In making this remark, Sir Jack shows an intuitive grasp of one of Postmodernity's most powerful realisations, namely that there is no "reality out there," beyond the reach of our pliable imagination, that the world no longer has that "rock-steady solidity" to which Bauman referred. In putting this potentially liberating insight into the mouth of a rather repulsive, larger-than-life, neoliberal tycoon, Barnes is illustrating another point that Bauman makes; that such realisations are not made first by philosophers, to then be distributed as "unofficial legislation" to the world, but rather exist in the collective experience long before they are given a thorough philosophical spelling-out by intellectual theoreticians.

The meaning of identity must change in a "world construed of durable objects (which) has been replaced with disposable products designed for immediate obsolescence" (88). In such a world, the slow painstaking lifelong construction of a career, a personality, a life, may prove in vain- "life-as-pilgrimage" is no longer feasible as a strategy. Yet, the inherent instability of modern life is not without its attractions, as one is also not so bound by the past, one is never irrevocably defeated, options can always be kept open. In a world where global economic forces often beyond the individual's comprehension apparently bring and take away benefits with increasing speed, and employment is a short-term compromise rather than a long-term commitment between those involved in the contract, seeing life as an enormous game played according to one set of rules is no longer feasible. Given that the rules apparently can change at short notice, it makes sense to play it as a series of short games, in which the notion of a life's vocation, or concepts such as consistency and 
loyalty are forgotten as outmoded. As the future cannot be controlled, at least by avoiding long-term commitments the successful player manages to avoiding mortgaging it. The trick, according to Bauman, is "to take care that the consequences of the game do not outlive the game itself, and to renounce responsibility for such consequences as do." In other words, "to forbid the past to bear on the present. In short, to cut the present off at both ends, to sever the present from history. To abolish time in any other form but a loose assembly, or an arbitrary sequence of present moments: to flatten the flow of time into a continuous present" (89). This point echoes the one made by Barnes, through Sir Jack-while time still flows, the illusion that landscape can be moved through persists; but the effective player of the Postmodern game realises they are in the landscape, that there is effectively no direction or flow. We could talk not only of the "detemporalisation of social space," mentioned earlier, but a contemporaneous "despacialisation of time."

Within such a world, says Bauman, the concept of "delay" loses its meaning - especially any notion of a "delay of gratification." What is the point of investing present effort for a future pay-off when there are no guarantees about the future? This devaluing of the concept of "delay" explains the tremendous emphasis now placed on the instant gratification that commodity consumption can promise. Its devaluing also effects some of the apparently fundamental tenets of education, where learning traditionally has involved absorbing information whose relevance at the time of its absorption was not always obvious —one thinks of those apparently interminable lists, of, for example, Spanish provinces, important rivers and prepositions, which so many can recite.

The instant gratification that underlies all of today's theme-park culture and much of the cultural heritage industry which has made such inroads into the Western European economy in the last twenty-five years, is clearly illustrated in Barnes' novel, by the fact that the contents of Sir Jack's theme-park, which purports to offer a cross-section of English cultu$\mathrm{re}$, is originally determined on the basis of market research done with "[p]otential purchasers of Quality Leisure in twenty-five countries [being] asked to list six characteristics, virtues or quintessences which the word England suggested to them" (83). The success with which the park attracts the "tall dollar and the long yen" depends not on selling information, a learning experience, but selling people back their own expectations, presented in a particularly well-designed and convenient package. Martha summarizes the secret of its success when Sir Jack first outlines his plan, and asks her opinion: "No-one lost money encouraging others to be lazy" (47).

The second part of Bauman's paper begins with the assertion that a strong notion of identity is something to be avoided as inconvenient in the postmodern world, as it becomes more a liability than an asset. He asserts, sententiously: "The hub of postmodern life strategy is not making identity stand-but the avoidance of being fixed" (89). He proposes therefore that the epitome of such avoidance is to be found in the figure of the Tourist. I will briefly spell out Bauman's arguments before offering some reservations of my own about this thought-provoking suggestion.

According to Bauman, the first key characteristics of the Tourist is that they manage not to belong to the place they are visiting, they are both in and out of place at the same time. 
By conjuring with temporary proximity while maintaining a distance, it is as if they were within a protective bubble, from which they can control the extent to which they interact with their temporary environment. Secondly, the Tourist travels lightly, so can take to the road at a moment's notice, and this ability is their freedom, autonomy and independence. Thirdly, the Tourist has no pre-planned itinerary, with length of stay and next destination generally being left undetermined, as, unlike the pilgrim, they have no particular goal beckoning them. If successive stays add up to an itinerary, then this is only constructed "retrospectively, when a logic is discovered or imputed which did not guide the wanderer at the time of his wandering" (90). Fourthly, the Tourist moves with sufficient regularity to avoid putting down roots, and in this "there is no mortgaging of the future, no incurring of long-term obligations" (90.). This allows the Tourist the feeling of being in control, although this control is not what Bauman terms a "heroic" control, in the sense that it does not impose itself upon the places where the Tourist stays, giving the environment a shape and form which reflects the hero's identity, as in Alexander the Great's passage through the Middle East. The Tourist's control is rather a "situational control," where point of contact with the world can be chosen, and this contact can be interrupted at will. As such, the Tourist leaves little mark in passing. And finally, unlike the vagabond, who is the Tourist's alter ego, the Tourist begins a trip by choice, and has a home to return to at will, even if the "home" which acts as consolation to the hardships of the road in prospect, turns into a prison once returned to, a prison from which the Tourist again yearns for open spaces.

It will be obvious by now from this brief summary of Bauman's main points that the Tourist he describes has little to do with the phenomenon of that name that springs to mind here in Spain. Perhaps 'Traveller' would be a more appropriate term for what Bauman is describing, as from the first Tourists who followed Sir Thomas Cook around Europe in the last century to the most adventurous client of a contemporary guided adventure holiday up the Amazon, predetermination of the itinerary and the experiences to be had are a fundamental component of the Tourist's contract with the tour company. As for the tourist not belonging at his current address, not staying long enough to set down roots, and exercising only a "situational control" on the environment which shapes the world in a way that is effortless and is inconsequential for the world, while that may be true of an individual tourist even in our modern, Spanish sense, it fails to take into account the fact that, in general, tourists do not move individually but en masse and this mass "situational control" does fundamentally reshape the world, by creating sites along the itinerary where the tourist does belong, more than anyone else. One thinks of those five-star tourist hotels throughout the developing world which provide home comforts for tourists while remaining virtually offlimits to the native population. My reservations here are not to discredit Bauman's metaphor, which is as richly suggestive and representative of the late twentieth-century mindset as, say, Dr. Jekyll and Mr Hyde are, or rather is, of that of the later Victorians.

It is also noticeable how in Barnes' fiction, central characters are often portrayed in the function of the Tourist, in a sense closer to Bauman's, as figures which move across the landscape in a fairly inconsequential way: the protagonist of the early Metroland frequently evokes the image of travelling the Metropolitan underground line, staring into people's backgardens and their lives while passing by unnoticed on the train; the narrator of Flau- 
bert's Parrot, whose travels through Flaubert's textual existence are far more resonant than his travels through the physical space around Rouen, which Flaubert once inhabited; the figure of Miss Moss, the protagonist of "Evermore," in the short-story collection Cross Channel, travelling like a ghost through the landscape of Northern France as she continues to commemorate her brother's death in the First World War, or the figure of the uncle who became involved in a Surrealist sex experiment while travelling through France for any of a variety of reasons, in "Experiment," from the same collection; in The History of the World in 10 and a Half Chapters, travel and travelling on the sea provide a unifying leitmotif for many of the stories, while Talking it Over ends with two of the main protagonists decamping to France, a decision to up roots if not to live a rootless existence. However, the sense of rootlessness, the flexibility of identity, and the apparent meaninglessness of past and future in an eternal present are characterised in Barnes' latest novel, both in the crass, pop culture of the England theme park, and in the protrayal of Martha Cochrane, an aspect of the book which has drawn much less critical attention.

The "flatten(ing of) the flow of time into a continuous present," which Bauman described as typical of the postmodern world, manifests itself in the strange ahistorical combinations which the park owners offer the paying public, such as the immensely popular attack by the SAS Iranian Embassy hit-squad on Robin Hood's cave, after the leader of the Merry Men has begun to behave like a real outlaw and started hunting the pigs in the park's rare English species collection, as an alternative to the $100 \%$ vegetarian roast "ox" provided by a very p.c. Friar Tuck. Such shockingly unauthentic combinations, however, are not only offered in the theme park. In the third section of the book, where Martha visits what remains of the real England, renamed Anglia, after it has long sunk into economic decline, she finds that the past has been largely abandoned as irrelevant. For example, the thoroughly convincing village farrier, Jez Harris, the local repository of folklore, with country sayings, such as, "They say redstarts bring luck to them as don't disturb their nests" (242), turns out to have been "Jack Oshinsky, junior legal expert with an American electronics firm" from Milwaukee who draws "inextinguishable pleasure ... (playing) the yokel whenever some anthropologist, travel writer or linguistic theoretician would turn up disguised as a tourist" (243). When the village decides to hold a traditional English summer fete, like the one which formed one of Martha's earliest memories in Part One of the book, they refuse her offer of an authentic regulation booklet on vegetable-growing competitions from her childhood for "the frail book seemed like a potsherd from an immensely complicated and self-evidently decadent civilisation" (247). The fete organisers therefore decide to start from scratch, and not feel restricted by any inconvenient loyalty to the past.

Barnes' protagonist, Martha, most nearly resembles Bauman's Tourist figure, in that as she struggles with her own notion of identity throughout the book, a struggle which parallels the questioning of what the essential identity of England is through the theme-park episode, she adopts some of the strategies Bauman suggests are the most effective means of living in the postmodern world. Martha's early attempt to construct a unified identity for herself and for her country are destined to frustration as she realises that her notion of her 'real' self is based on memories, which do not go back to contact an original experience, but are memories of memories of earlier memories, and so on ad infinitum, and so cannot 
be trusted as a means of recovering the past. In the same way, symbolically, her inability to complete the jigsaw puzzle of England (in which each county was a piece) since her father abandoned her and her mother one day going off with Northamptonshire in his pocket, suggests that any national identity is forever doomed to remain incomplete. Her time with Pitco, her conversations with Dr Max and her passing emotional relationship with Paul all further undermine notions that past and/or future can be trusted as fields in which to construct a solid sense of identity. If parts one and two of England, England represent Martha's learning the necessity of travelling as a "Tourist," in Bauman's sense, the completion of this learning process paradoxically allows her to stop travelling and to develop a new sense of identity, when she arrives as an old maid in Anglia in part three. For there her selfconscious preoccupation with questions of her own identity and the meaning of her life finally cease, and she derives more sense of identity from the immediate community and environment that surrounds her. The puzzle and its missing piece, which symbolise the impossibility of resolving the problem of identity construction, are evoked in the sentence: "[E]ventually she herself fitted into the village, because she herself no longer itched with her own private questions. She no longer debated whether or not life was a triviality, and what the consequences might be if it were. Nor did she know whether the stillness she had attained was proof of maturity or weariness" (257). It is apparent from this that her integration into the community is an inverse of her search for meaning as an individual identity.

Bauman's Tourist represents a condition which perhaps we recognise as familiar, a tendency to live life superficially which has something sterile and cowardly about it. It is best seen as an aspect of the detachment which must be acquired in order for a character such as Martha, or indeed us, to be able to overcome the limitations of a thoroughly ego-centred sense of identity, which is bound to lead to constant upset and discomfort, in order to develop a sense of identity which is derived more from an acceptance of and identification with those around us. Despite the Tourist's best efforts to live life as a series of episodes, each ending on the official understanding of "not to be continued," the Tourist's life can never be final, as Bauman recognises, "the past may come back to haunt us" and despite the Tourist's self-protecting bubble, "there is (always) a hole through which the world out there breaks time and again into the tightly controlled space-thereby calling the bluff of the tourist's control. This is why the tourist's life is not all roses" (91).

The moments when the world out there breaks in, in Barnes' novel, are, for example, those moments during Martha's time working for the theme-park when the actors playing prescribed roles begin to live the roles with an earnestness which threatens the smooth operation of the park's attractions, as when Robin Hood repels the SAS hit-squad, and when the actor playing Samuel Johnson speaks from the world-weary depths of his (assumed) soul when called in for a disciplinary talk with Martha after he had upset a French customer by not producing the witty banter expected during the Evening with Samuel Johnson at the Cheshire Cheese Experience. Invariably, Martha finds these episodes heartening personally, even when professionally she is being called upon to express disapproval.

Just as Rorty felt Dickens' work as testimonial embodied more truth than Heidegger, so I would argue that Barnes' novel takes us beyond Bauman's model, by showing that it is as 
a waystage on a longer trip, a trip in which the trivial superficiality of the postmodern Tourist's relationship to the world can be seen as a positive advance towards the construction of a more lasting, deeper sense of identity.

\section{WORKS CITED}

Barnes, Julian. England, England. London: Jonathan Cape, 1998.

Bauman, Zygmunt. Postmodernity and its Discontents. London: Polity Press, 1996. 